\title{
Atividade Psicrotrófica e Proteolítica de Enterobactérias Isoladas de Carcaças de Frangos
}

Camila Lampugnani (I), Ana Paula Perin (I), Rosangela Estel Ziech (I), Mallu Jagnow Sereno (I), Cibeli Viana (I), Luciano dos Santos Bersot (I)

(I) UFPR - Universidade Federal do Paraná - Setor Palotina (Rua Pioneiro, 2153, Bairro Jardim Dallas, Palotina, PR)

\section{Resumo}

A contagem de bactérias da família Enterobacteriaceae é realizada como forma de monitoramento dos níveis de contaminação fecal nas carcaças servindo, desta forma, como micro-organismos indicadores durante $\mathrm{o}$ processo. Algumas espécies desta família têm a capacidade de se multiplicar em temperaturas de refrigeração, sendo denominadas psicrotróficas. Os psicrotróficos são conhecidos por produzirem enzimas capazes de causar proteólise e lipólise de produtos de origem animal, ocasionando prejuízos econômicos para as indústrias pela deterioração que promovem. O objetivo deste trabalho foi avaliar a atividade psicrotrófica e proteolítica de enterobactérias isoladas de carcaças de frangos. As análises foram realizadas no Laboratório de Inspeção e Controle de Qualidade de Alimentos e Água (LACOMA) da UFPR, Palotina. No período de julho de 2013 a junho de 2014 foram analisadas 152 cepas de enterobactérias provenientes de 39 amostras de carcaças de frango oriundas de um matadouro-frigorífico da região oeste do Paraná. Para a contagem de enterobactérias foi utilizada a metodologia $3 \mathrm{M}^{\mathrm{TM}}$ Petrifilm ${ }^{\mathrm{TM}}$ EB. Para verificação da atividade psicrotrófica e proteolítica, as colônias foram repicadas em ágar leite desnatado e incubadas à $7^{\circ} \mathrm{C}$ por dez dias. As cepas que formaram colônias após o período de incubação foram consideradas psicrotróficas e as que apresentaram a formação de um halo translúcido de hidrólise da caseína, foram consideradas proteolíticas. Observou-se que

\footnotetext{
Referência:

Camila Lampugnani, Ana Paula Perin, Rosangela Estel Ziech, Mallu Jagnow Sereno, Cibeli Viana, Luciano dos Santos Bersot.Atividade Psicrotrófica e Proteolítica de Enterobactérias Isoladas de Carcaças de Frangos. In: Anais do 12º Congresso Latinoamericano de Microbiologia e Higiene de Alimentos - MICROAL 2014 [= Blucher Food Science Proceedings, num.1, vol.1]. São Paulo: Editora Blucher, 2014. 
36/152 cepas (24\%) apresentaram-se psicrotróficas e, deste total, 7/36 (19\%) apresentaram atividade proteolítica. Ao observar os resultados por amostra de carcaça analisada, 19/39 (49\%) apresentaram pelo menos uma cepa de enterobactéria psicrotrófica e destas 19 amostras, em cinco foram encontradas cepas com atividade proteolítica (26\%). Os dados indicaram que praticamente um quarto das cepas de enterobactérias isoladas de carcaças de frangos foram psicrotróficas. Conclui-se que os percentuais de cepas de enterobactérias psicrotróficas isoladas e sua atividade proteolítica é um importante alerta para a indústria de abate de frangos, uma vez que grupos de micro-organismos sabidamente indicadores de contaminação fecal ou de condições higiênico-sanitárias também podem representar sua possibilidade potencial de deterioração do produto em refrigeração.

Palavras-Chave: micro-organismos indicadores, deterioração, refrigeração, qualidade

\section{Agência de Fomento:}

